\title{
Inhalt
}

Vorwort der Herausgeber.

Leo Baeck. Rabbiner und Lehrer

von Werner Licharz

VORREDE

\section{VOM GLAUBEN}

Vollendung und Spannung ................................................... 29

Geheimnis und Gebot......................................................... 45

Tod und Wiedergeburt ........................................................ 55

Geist und Blut ............................................................................. 70

Die Mystik im Judentum ............................................................ 82

Bedeutung der jüdischen Mystik für unsere Zeit .................. $\quad 86$

Das Geistige im Wohltun ...................................................... 91

\section{BINDUNGEN UND WEGE}

Kulturzusammenhänge ....................................................... 101

Lebensgrund und Lebensgehalt .......................................... 112

Boden, Erde, Welt ............................................................... 123

Religion und Erziehung …..................................................... 129

Natur und Weg ........................................................................ 139

Philosophie und Religionsunterricht .................................... 142 


\section{GESCHICHTE UND KAMPF}

Weltgeschichte

Volksreligion und Weltreligion ............................................ 154

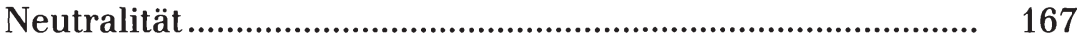

Staat, Familie, Individualität ................................................ 173

Friedensbahn und Friedensziel ........................................... 176

Wohlfahrt, Recht und Religion ............................................. 181

\section{ZIEL UND WIDERSTREIT}

Das Judentum ..................................................................... 193

Jüdische Religion der Gegenwart ......................................... 199

Zwischen Wittenberg und Rom .............................................. 206

Gemeinde in der Großstadt ................................................. 218

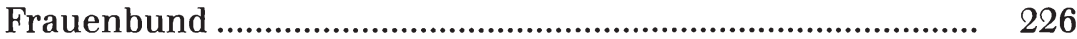

Predigt und Wahrheit ............................................................. 232

\section{MENSCHEN UND GESCHICKE}

Motive in Spinozas Lehre .................................................. $\quad 243$

Moses Mendelssohn ........................................................... 251

Nehemia Anton Nobel. Über schöpferische

Empfänglichkeit ............................................................... 265

Franz Rosenzweig. Über Bildung ........................................... 269

Eugen Caspary. Über den bürgerlichen Menschen .............. 277

\section{HOCHSCHULE UND AKADEMIE}

Heimgegangene des Krieges. Über den preußischen Staat ... 285

Helfer und Lehrer. Über Mittelalter und neue Zeit .............. 297

Gustav Bradt. Über Begabung ................................................ 311

QUELLENNACHWEIS ...................................................... 317 